\title{
COMPLICAÇÕES CIRÚRGICAS RELACIONADAS AO TRATAMENTO DE PACIENTES PORTADORES DE DEFORMIDADES DENTO-FACIAIS
}

Rafael SANTOS, Delson João da COSTA, Matheus Sabóia MARCONDES, Nelson Luis Barbosa REBELLATO, Paulo Roberto MÜLLER

Complicações em cirurgias ortognáticas podem ocorrer, e efetivamente ocorrem, com praticamente todos os cirurgiões envolvidos no tratamento de pacientes portadores de deformidades buco-maxilo-faciais. As complicações trans-operatórias são mais freqüentes como decorrência de não observância de detalhes da técnica cirúrgica ou de falhas de avaliação da anatomia do paciente. Segundo O'RYAN (1989) elas são divididas em separações ósseas desfavoráveis, hemorragias, lesões nervosas, mau posicionamento do segmento proximal e dificuldades técnicas menores. Um amplo entendimento das bases biológicas para o planejamento do procedimento, a correta avaliação da natureza da deformidade, a probabilidade de ocorrência de um determinado tipo de complicação antes, durante ou após a cirurgia, os mecanismos para a prevenção e o correto tratamento destas, se constituem na essência do conhecimento, necessárias para o correto tratamento dos pacientes. Através de uma revisão de literatura este trabalho visa apresentar complicações que podem ocorrer durante a cirurgia ortognática e a maneira encontrada para solucionar tais situações. 